\title{
BUSINESS PLANNING AND ASSESSMENT OF ITS IMPACT ON THE ENTERPRISE FINANCIAL STABILITY
}

\author{
Kateryna Shtepenko*, Senior Lecturer, \\ Lyudmyla Svystun**, PhD (Economics), Associate Professor \\ Iryna Krekoten***, PhD (Economics), Associate Professor \\ National University «Yuri Kondratyuk Poltava Polytechnic»
}

\author{
* ORCID 0000-0002-2677-750X \\ * ORCID 0000-0002-6472-9381 \\ * ORCID 0000-0003-0107-2359 \\ (C) Shtepenko K., 2020. \\ (C) Svystun L., 2020. \\ (C) Krekoten I., 2020.
}

Стаття отримана редакиією 15.12.2020 p.

The article was received by editorial board on 15.12.2020

Introduction. The process of successful operation and development of the enterprise in a market economy depends on the level of its economic stability, so in recent years, sustainable development of the enterprise has become one of the priority strategic objectives. Fluctuations in economic activity, the crisis in the real economy and the financial system of Ukraine have significantly affected the sustainability of economic entities, demonstrated their weaknesses.

In practice of the economic entities activities study, one of the most common and used for decisionmaking is the analysis of financial condition. Conducting of this provides various stakeholders with an opportunity to obtain the necessary information base. In particular, information support for decisions of management, creditors, investors and counterparties etc. is provided. Still, a question remains relevant, to what extent the existing methods of analysis meet the needs of users considering the dynamism and diversity of economic processes at the present stage of an enterprise development as an open socio-economic system.

Analysis of recent research sources and publications. The listed below works by the domestic and foreign scholars are dedicated to the study of theoretical and methodological principles and development of methods for financial condition of the enterprise analyzes: O. Andriichuk, O. Arefieva, L.A. Bernstein, I.O. Blanc, F.F. Butynets, E. Helfert, V.V. Kovalov, M.Ya. Korobov, O. Kolodiziev, L.A. Lakhtionova, J. Richard, V.S. Rudnytskyi, H.V. Savytska, V.K. Savchuk, A.D. Sheremet, Yu.S. Tsal-Tsalko, I. Vinichenko et al. [1-7]. The article by V.V. Mokeev, E.V. Bunova and A.V. Perevedentseva describes the methodology for analyzing the stability of an enterprise. It provides formulas for calculating the complex indicator of economic and financial stability [8]. The Malek's study has identified 29 enablers of sustainable manufacturing. Interpretive Structural Modeling has been utilized by Malek to develop a hierarchy structural model which can represent the interrelationships among the enablers of enterprise sustainability [9]. I. Vinichenko studies the components of agricultural enterprises economic and financial stability [10].

However, while studying this complex problem, the following questions remain unresolved: adequacy of the system of analytical indicators of the object of study state as a system; significance of individual indicators; compliance of the system of indicators to object dynamics; logical linking of indicators (considering the relationship between different subsystems); validity of normative values of indicators, including those for different stages of the object development.

The purpose of the article. This study substantiates relevant relationships between static and dynamic indicators of financial condition, which reflect its characteristics such as business activity and financial stability.

Results. Developed methods for financial condition analysis with their characteristic features of indicators systems application and recommended standard values for their interpretation are at the disposal of users [1-3, 7]. Liquidity indicators characterize the optimal composition and structure of the enterprise assets and liabilities from the standpoint of ensuring its solvency. Indicators of financial stability enable 
estimating long-term solvency and level of financial risk. Turnover indicators characterize efficiency of property use and level of the enterprise business activity.

The problem of the system of indicators applying is its most rational selection, which, on the one hand, would avoid their duplication (in economic terms), and on the other - to cover all the important characteristics of the object under study. Whilst significance of different characteristics may vary, which should be taken into account in particular when calculating the integrated indicators of financial condition. The accurate selection of analytical tools also depends on the clarity of defining the financial condition category as the object of research.

The logic of constructing a "financial condition of the enterprise" economic category definition involves its consideration primarily from the standpoint of the reproduction process and submission to the laws of the market. In general, this category reveals economic relations, covering a wide range of monetary relations associated with the formation, placement and use of financial resources, cash, capital, income in the process of their circulation, which form the financial mechanism for socio-economic development of the enterprise provision, ability to function and develop in a changing external environment, current and perspective opportunities to meet the requirements of creditors, as well as its investment attractiveness.

On the one hand, financial condition of the enterprise as the basis of its competitiveness reflects the enterprise real and potential capabilities, which are formed in the process of production, commercial, financial and investment activities, its self-financing ability, as well as characterizes the level of financial resources endowments, necessary for the enterprise regular functioning and development in the long-term perspective, expediency of their placement and efficiency of use. On the other hand, it determines financial relations with other legal entities and individuals, the enterprise's ability to operate in the external environment, its potential in business cooperation, allows assessing investment attractiveness and determining the company's position in domestic and other ratings.

Financial condition changes in one way or another after almost each business transaction. In addition, its dynamics is determined by the development of the enterprise at different stages of the life cycle. Still traditional indicators of financial condition have different (and therefore difficult to compare) dynamism characteristics. That is why occurs an objective need to improve the methodological approach to the analysis of the enterprise financial condition, taking into account its variability. Thus, indicators of financial stability and liquidity are determined at a fixed point of time and do not indicate the state between the moments at the beginning and end of the reporting period. In this context, stasis of these indicators is objective, as they are determined on the basis of financial statements fixed balances; in addition, creditworthiness is an ability to settle liabilities in a certain period (the obligation time). On the other hand, however, the ability that arises at a certain point of time is a consequence of the process that has a certain set of qualitative and dynamic characteristics. Thus, liquidity (if to consider it not only in terms of balance of payments or balance sheet) is characterized by a certain quality, properties of assets, as well as features of the sources of asset formation and depends on the efficiency of their use. These properties, in turn, are determined by a number of internal and external factors related with the quality of production assets, staff qualifications, production process organization level, composition and conditions of own and borrowed funds formation, etc., which determine the dynamics of asset formation and use.

Regarding the dialectic of the indicators dynamics understanding, it is established that business activity indicators are characterized by higher dynamics, while current assets turnover indicators, which are determined on the basis of data for the period, reflect the process efficiency of their use.

Based on the system approach, it is established that substantiation of the indicators system and their dynamics is closely related to the relationship between individual groups of financial condition indicators. In this context, it is important to explore the interdependencies of financial stability and business activity, whereas they reflect two most important criteria in financial management, which are efficiency and risk.

Peculiarity of the study of financial stability indicators relationship with business activity indicators is that the former are determined statically (at a certain point of time) based on balances at the beginning or end of the period, and the latter - dynamically, reflect data for the study period and are determined on the basis of average indicators and turnover (in particular, the turnover ratio of assets $\left(G_{\mathrm{A}}\right)$, which is determined by the ratio of net income (NI) to the average value of assets (A)):

$$
\mathrm{O}_{\mathrm{A}}=\frac{\mathrm{NI}}{\overline{\mathrm{A}}}=\frac{2 \mathrm{NI}}{\mathrm{A}_{0}+\mathrm{A}_{1}}
$$

where $\mathrm{A}_{0}, \mathrm{~A}_{1}$ indicate assets value respectively at the beginning and the end of the period under study. 
This indicator characterizes the speed of economic means undergoing all the stages of their cycle and shows how many circulations they make during the study period (year). Its increase contributes to the growth of financial results, growth of the level of creditworthiness, and in general indicates an increase in business activity.

To reflect the relationship between financial stability and business activity, this model must be transformed by dividing the numerator and denominator of the fraction (1) by the average equity:

$$
\mathrm{AT}=\frac{2 \mathrm{NI}}{\frac{\mathrm{EC}_{0}+\mathrm{EC}_{1}}{\frac{\mathrm{A}_{0}+H_{1}}{\mathrm{EC}_{\mathrm{0}}+\mathrm{EC}_{1}}}}
$$

As a result of conversion in the numerator of the fraction we get the turnover of equity (ROE). This indicator reflects the volume of sales per unit of equity and characterizes the turnover rate of the latter. In the system of the enterprise business activity indicators, it is used to assess the effectiveness of resource management and participation of owners. Considering the formula (2) we get:

$$
A T=\frac{\operatorname{ROE}\left(\mathrm{EC}_{0}+\mathrm{EC}_{1}\right)}{\mathrm{A}_{0}+\mathrm{A}_{1}}=\frac{\operatorname{ROE}\left(2 \frac{\mathrm{EC}_{1}}{\mathrm{~A}_{1}}-\frac{\Delta \mathrm{EC}}{\mathrm{A}_{1}}\right)}{2-\frac{\Delta \mathrm{A}}{\mathrm{A}_{1}}}
$$

Considering that

$$
\frac{\mathrm{EC}_{1}}{\mathrm{~A}_{1}}=\mathrm{R}_{N 1}
$$

Thus

$$
A T=\frac{R O E\left(2 R_{N_{1}} * \mathrm{~A}_{1}-\Delta \mathrm{EC}\right)}{2 \overline{\mathrm{A}}}
$$

where $\mathrm{RN}_{1}$ is a coefficient of financial independence at the end of the period. From here:

$$
\mathrm{R}_{N_{1}}=\frac{\left(2 \frac{\mathrm{AT}}{\mathrm{ROE}} * \overline{\mathrm{A}}+\Delta \mathrm{EC}\right)}{2 \mathrm{~A}_{1}}
$$

It is necessary to investigate separately the ratio of asset turnover to equity turnover $\left(\mathrm{C}_{\mathrm{t}}\right)$ :

$$
C_{t}=\frac{A T}{\mathrm{ROE}}
$$

On the one hand, this indicator reflects the dynamics of the structure of activity funding sources (i.e. financial stability). With increase in the share of equity on the average balance sheet, $\mathrm{C}_{\mathrm{t}}$ approaches 1 , and with its decreases, it approaches zero. On the other hand, ROE can be interpreted as a characteristic of the assets turnover generated from own sources. The closer $C_{t}$ approaches 1 , the greater the load on its own sources. This means that at expense of the own sources, different parts of current assets with greater liquidity and turnover are formed, assuming that their main purpose is to cover non-current and production current assets. Therefore, from a financial point of view, under a $C_{t}$ high value (when the turnover of assets is close to the turnover of equity), the efficiency of using own sources decreases. On the contrary, the smaller $\mathrm{C}_{\mathrm{t}}$, the bigger the turnover of UAH 1 invested in own sources, though the risk of losing financial stability increases.

Thus, the ratio of asset turnover to equity turnover $\left(\mathrm{C}_{t}\right)$ can be considered as an indicator that expresses the dynamic relationship between financial stability and efficiency of capital use.

The disadvantage of $\mathrm{C}_{\mathrm{t}}$ is that it does not reflect the absolute effect, that is why it is advisable to take into account the dynamics of net income separately.

However, the ratio of asset turnover and equity turnover is a certain dynamic lever that reflects the intensity of equity sources use.

Let's mark:

Let us denote:

$$
\mathrm{R}_{N 1}=\frac{2 \mathrm{~A}_{1}\left(\mathrm{C}_{\mathrm{t}}\left(1-\frac{\Delta \mathrm{A}}{2 \mathrm{~A}_{1}}\right)+\frac{\Delta \mathrm{EC}}{2 \mathrm{~A}_{1}}\right)}{2 \mathrm{~A}_{1}}
$$




$$
\frac{A A}{A_{1}}=G_{A}
$$

where $G_{A}$ is asset growth rate. Then:

$$
R_{N_{1}}=\mathrm{C}_{\mathrm{t}}\left(1-\frac{1}{\frac{2}{\mathrm{G}_{\mathrm{A}}}+2}\right)+\frac{\Delta \mathrm{EC}}{2 \mathrm{~A}_{1}}
$$

The equity increase can be represented as follows:

$$
\Delta \mathrm{EC}=R_{N 1} * \mathrm{~A} 1-R_{N 0} * \mathrm{~A}_{0}
$$

where $\mathrm{RN}_{0}$ is the coefficient of financial independence at the beginning of the period. Then:

$$
\frac{\Delta \mathrm{EC}}{\mathrm{A}_{1}}=\frac{\mathrm{R}_{N 1} * \mathrm{~A}_{1}}{\mathrm{~A}_{1}}-\frac{\mathrm{R}_{N 0} * \mathrm{~A}_{0}}{\mathrm{~A}_{1}}=\mathrm{R}_{N 1}-\frac{1}{\frac{1}{\mathrm{R}_{N 0}} * \frac{A_{1}}{A_{0}}}=R_{N 1}-\frac{1}{\frac{1}{\mathrm{R}_{N 0}}\left(1+\mathrm{G}_{\mathrm{A}}\right)}
$$

Considering (10) and (11):

$$
\mathrm{R}_{N 1}=\mathrm{C}_{\mathrm{t}}\left(1-\frac{1}{\frac{2}{\mathrm{G}_{\mathrm{A}}+2}}\right)+\frac{1}{2}\left(\mathrm{R}_{N 1}-\frac{1}{\frac{1}{\mathrm{R}_{N_{0}}}\left(1+\mathrm{G}_{\mathrm{A}}\right)}\right)
$$

Or after simplifying:

$$
\mathrm{R}_{N 1}=\frac{\mathrm{C}_{\mathrm{t}}\left(2+\mathrm{G}_{\mathrm{A}}\right)-\mathrm{R}_{N O}}{1+\mathrm{G}_{\mathrm{A}}}
$$

This dependence combines static indicators with dynamic ones, enables determining the impact of the enterprise business activity level on its financial stability, so it can be used in both retrospective and prospective analysis. Since the relationship between the performance indicator and the factors that form it in the combined model is rigidly determined, it is advisable to use the method of chain substitutions while evaluating the influence of factors. Due to the fact that in this method the magnitude of the change in the generalized indicator under the influence of the factor depends on the sequence taken in the calculation, it is necessary to be justified.

The quantitative parameter of model (13) is the coefficient of financial independence at the beginning of the period $\left(\mathrm{RN}_{0}\right)$, it is basic in comparative analysis and characterizes the initial structure of economic resources sources. The influence of this factor should be firstly determined. The growth rate of $G_{A}$ assets reflects the dynamics of the process and chronologically characterizes the changes that occurred after the moment for $\mathrm{RN}_{0}$. It must be considered as a secondary factor. Qualitative indicator $\mathrm{Ct}$ is the result of dynamic interaction of quantitative and structural indicators and reflects the qualitative characteristics, namely the efficiency of property use from the standpoint of optimizing the structure of its formation sources. The influence of this factor must be determined in the third order.

The study of the relationship between indicators of business activity and financial stability was conducted on the basis of the enterprise activities data for 2012-2019 (Table 1).

Table 1

The enterprise activities main indicators

\begin{tabular}{|l|l|l|r|r|r|r|r|l|}
\hline \multirow{2}{*}{ Indicators } & \multicolumn{10}{|c|}{ Years } \\
\cline { 2 - 9 } & \multicolumn{1}{|c|}{2012} & \multicolumn{1}{|c|}{2013} & 2014 & 2015 & 2016 & 2017 & 2018 & 2019 \\
\hline $\mathrm{NI}$ & 44670,4 & 45740 & 67027 & 94390 & 104128 & 130411 & 131806 & 128863 \\
\hline $\mathrm{A}_{0}$ & 16540 & 26376,9 & 35964 & 40746 & 47642 & 80969 & 78625 & 71584 \\
\hline $\mathrm{A}_{1}$ & 26376,9 & 35964 & 40746 & 47642 & 80969 & 78625 & 71584 & 67287 \\
\hline $\mathrm{EC}_{0}$ & 7887,1 & 10054,7 & 10653 & 13537 & 17624 & 21586 & 25425 & 27754 \\
\hline $\mathrm{EC}_{1}$ & 10054,7 & 10653 & 13537 & 17624 & 21586 & 25425 & 27754 & 29108 \\
\hline
\end{tabular}


Based on the data from Table 1, the input information for the analysis of the financial stability model (6) is generated. The results of the calculations are presented in table 2.

Input data for the enterprise financial stability $\left(\mathrm{RN}_{1}\right)$ model analysis

Table 2

\begin{tabular}{|l|c|c|c|c|c|c|c|c|}
\hline \multirow{2}{*}{ Indicators } & \multicolumn{7}{|c|}{ Years } \\
\cline { 2 - 9 } & 2012 & 2013 & 2014 & 2015 & 2016 & 2017 & 2018 & 2019 \\
\hline $\mathrm{G}_{\mathrm{A}}$ & 2,082 & 1,467 & 1,748 & 2,136 & 1,619 & 1,634 & 1,755 & 1,856 \\
\hline $\mathrm{ROE}$ & 4,979 & 4,418 & 5,542 & 6,058 & 5,311 & 5,548 & 4,957 & 4,532 \\
\hline $\mathrm{Ct}$ & 0,418 & 0,332 & 0,315 & 0,353 & 0,305 & 0,295 & 0,354 & 0,409 \\
\hline $\mathrm{RN}_{0}$ & 0,477 & 0,381 & 0,296 & 0,332 & 0,370 & 0,267 & 0,323 & 0,388 \\
\hline $\mathrm{RN}_{1}$ & 0,381 & 0,296 & 0,332 & 0,370 & 0,267 & 0,323 & 0,388 & 0,433 \\
\hline $\mathrm{G}_{\mathrm{A}}$ & 0,595 & 0,363 & 0,133 & 0,169 & 0,700 & $-0,029$ & $-0,090$ & $-0,060$ \\
\hline
\end{tabular}

Thus, the level of financial stability shows a negative trend until 2017. And while in 2018-2019 the value of the financial independence coefficient began to grow, its level for the entire study period was below the normative value. Some strengthening of financial stability took place under the negative dynamics of assets background, which indicates a decrease in liabilities of the enterprise.

To conduct a factor analysis, the dynamics of the input indicators of the financial stability model is determined (Table 3).

Input indicators dynamics of the enterprise financial stability model

Table 3

\begin{tabular}{|l|l|l|l|l|l|l|c|}
\hline \multirow{2}{*}{ Indicators } & \multicolumn{7}{|c|}{ Absolute deviation } \\
\cline { 2 - 8 } & 2013 p. & 2014 p. & 2015 p. & 2016 p. & 2017 p. & $2018 \mathrm{p}$. & $2019 \mathrm{p}$. \\
\hline $\mathrm{RN}_{0}$ & $-0,0957$ & $-0,0850$ & 0,0360 & 0,0377 & $-0,1033$ & 0,0568 & 0,0643 \\
\hline $\mathrm{G}_{\mathrm{A}}$ & $-0,2313$ & $-0,2305$ & 0,0363 & 0,5303 & $-0,7285$ & $-0,0606$ & 0,0295 \\
\hline $\mathrm{Ct}$ & $-0,0859$ & $-0,0168$ & 0,0372 & $-0,0477$ & $-0,0103$ & 0,0595 & 0,0554 \\
\hline $\mathrm{RN}_{1}$ & $-0,085$ & 0,036 & 0,0377 & $-0,1033$ & 0,0568 & 0,0643 & 0,0449 \\
\hline
\end{tabular}

Table 4 presents the results of calculating the influence of factors on the change in $\mathrm{RN}_{1}$ in 2013-2019 compared to the value of the corresponding previous period.

Table 4

Impact of factors to change in $\mathrm{RN}_{1}$

\begin{tabular}{|l|l|l|l|l|l|l|l|}
\hline & \multicolumn{7}{|c|}{ The impact magnitude over the years } \\
\cline { 2 - 9 } Influence factor & 2013 p. & 2014 p. & 2015 p. & 2016 p. & 2017 p. & 2018 p. & 2019 p. \\
\hline $\mathrm{RN}_{0}$ & 0,0600 & 0,0623 & $-0,0318$ & $-0,0322$ & 0,0608 & $-0,0585$ & $-0,0707$ \\
\hline $\mathrm{G}_{\mathrm{A}}$ & 0,0039 & 0,0054 & 0,0005 & 0,0046 & 0,0169 & $-0,0020$ & 0,0012 \\
\hline $\mathrm{Ct}$ & $-0,1489$ & $-0,0317$ & 0,0690 & $-0,0757$ & $-0,0209$ & 0,1248 & 0,1144 \\
\hline Total & $-0,085$ & 0,036 & 0,0377 & $-0,1033$ & 0,0568 & 0,0643 & 0,0449 \\
\hline
\end{tabular}

The conducted calculations enable accepting certain characteristics of the model. A comparison of the data in Tables 3 and 4 shows that unlike other factors, the effect of $G_{A}$ on $\mathrm{RN}_{1}$ is not stable. In some cases (years 2013, 2014, 2015) a decrease in $\mathrm{G}_{\mathrm{A}}$ leads to an increase in $\mathrm{RN}_{1}$, and in others (2018) - to its decrease. This is due to the fact that the effect of $\mathrm{G}_{\mathrm{A}}$ directly depends on the value of $\mathrm{Ct}$. To identify this internal dependence, it is advisable to calculate the effect of $G_{A}$ on $R_{1}$ under different values of $C_{t}$. Upon this, value of $\mathrm{RN}_{0}$ must be fixed at a constant level. In our chosen case (Table 5) $\mathrm{RN}_{0}=0.6$.

In the ratio $C t / R N 0=1$, (Table 5 , under the condition $C_{t}=0.6$ ), the effect of the $G_{A}$ change to $R_{1}$ (regardless of the direction of this change) is equal to zero. If $C_{t}$ is bigger than $R N_{0}$, then the effect of $G_{A}$ change to $\mathrm{RN}_{1}$ is inverted to the direction of $\mathrm{G}_{\mathrm{A}}$ change. Thus, in 2013, 2014, 2017 and 2018 the $\mathrm{G}_{\mathrm{A}}$ index was decreasing while its effect on $\mathrm{RN}_{1}$ under $\mathrm{C}_{\mathrm{t}}$ bigger than 0.6 was positive. Conversely, in 2015, 2016 and 2019 the $G_{A}$ index was increasing, and its effect on $R_{1}$ under $C_{t}$ bigger than 0.6 was negative. When $C_{t}$ is 
smaller than $\mathrm{RN}_{0}$, the effect of the $\mathrm{G}_{\mathrm{A}}$ change to $\mathrm{RN}_{1}$ is direct. In 2013, 2014, 2017 and 2018, with $\mathrm{C}_{\mathrm{t}}$ smaller than 0.6, the effect of the $\mathrm{G}_{\mathrm{A}}$ change to $\mathrm{RN}_{1}$ was negative, and in 2015, 2016 and 2019, under the same value of $\mathrm{C}_{\mathrm{t}}$, this effect was positive.

Table 5

Dependence of the direction of $G_{A}$ influence on $R N_{1}$ at different ratios of $C_{t}$ to $R N_{0}$

\begin{tabular}{|c|c|c|c|c|c|c|c|c|c|c|}
\hline \multirow{2}{*}{ Years } & \multirow{2}{*}{$\mathrm{G}_{\mathrm{A}}$} & \multirow{2}{*}{$\Delta \mathrm{G}_{\mathrm{A}}$} & \multicolumn{8}{|c|}{$\Delta \mathrm{RN}_{1}\left(\mathrm{G}_{\mathrm{A}}\right)$ under $\mathrm{RN}_{0}=0,6$} \\
\cline { 5 - 12 } & & & $\mathrm{Ct}$ & 0,3 & 0,4 & 0,5 & 0,6 & 0,7 & 0,8 & 0,9 \\
\hline 2012 & 0,595 & - & - & - & - & - & - & - & - & - \\
\hline 2013 & 0,363 & $-0,231$ & - & $-0,032$ & $-0,021$ & $-0,011$ & 0,000 & 0,011 & 0,021 & 0,032 \\
\hline 2014 & 0,133 & $-0,230$ & - & $-0,045$ & $-0,030$ & $-0,015$ & 0,000 & 0,015 & 0,030 & 0,045 \\
\hline 2015 & 0,169 & 0,036 & - & 0,008 & 0,005 & 0,003 & 0,000 & $-0,003$ & $-0,005$ & $-0,008$ \\
\hline 2016 & 0,700 & 0,530 & - & 0,080 & 0,053 & 0,027 & 0,000 & $-0,027$ & $-0,053$ & $-0,080$ \\
\hline 2017 & $-0,029$ & $-0,728$ & - & $-0,132$ & $-0,088$ & $-0,044$ & 0,000 & 0,044 & 0,088 & 0,132 \\
\hline 2018 & $-0,090$ & $-0,061$ & - & $-0,021$ & $-0,014$ & $-0,007$ & 0,000 & 0,007 & 0,014 & 0,021 \\
\hline 2019 & $-0,060$ & 0,030 & - & 0,010 & 0,007 & 0,003 & 0,000 & $-0,003$ & $-0,007$ & $-0,010$ \\
\hline
\end{tabular}

Thus, in this case there is a kind of dynamic lever, which shows that if the ratio of asset turnover and return on equity over the ratio of financial independence at the beginning of the period of increasing the value of assets will have a negative impact on financial stability.

Conclusions. Thus, the considered dependencies make it possible to thoroughly investigate the individual characteristics of the financial condition based on the relationship between their static and dynamic parameters. The ratio of asset turnover and equity characterizes the efficiency of use and formation the property structure of sources, as well as creates a basis for assessing the impact of qualitative indicators of business activity on financial stability. The study of the interdependence between the asset ratio to equity turnover (3) and the financial independence ratio at the beginning of the period revealed its relationship with the dynamics indicators, which can be described as the action of dynamic leverage. Depending on the value of this ratio (bigger or smaller one), the impact of property growth on financial stability will be negative or positive. This feature can be used both in retrospective analysis to study the relationship between efficiency and risk, and to predict financial stability.

\section{REFERENCES:} Petersburg.

1. Helfert E. (2003), Metodika finansovogo analiza [Financial Analysis Technique], PITER, St.

2. Tsal-Tsalko, Yu. S. (2008), Finansovyi analiz [Financial Analysis], Tsentr uchbovoi literatury, Kyiv.

3. Sheremet, A. D. and Sayfulin R. S. (1995), Metodika finansovogo analiza [Financial analysis technique], INFRA-M, Moscow.

4. Andriichuk O. and Buryi S. (2011), "Management of economic stability of the enterprise", Bulletin of Khmelnytskyi National University, Vol. 6, Issue 1, pp.100-102.

5. Arefieva O. and Horodianska D. (2008), "Economic stability of the enterprise: essence, components and measures of its maintenance”, Current economic problems, Vol. 8, pp. 83-90.

6. Kolodiziev O. and Nuzhnyi K. (2007), "Research of the essence and content of economic stability of the enterprise”, Municipal utilities, Vol 78, pp.238-243.

7. Slobodian, N.H. (2014), "Analysis and forecasting of financial stability of the enterprise in modern conditions: methodology and practice”, Ekonomichnyj analiz: zb. nauk. prats' [Economic analysis: collection of scientific works], Ternopil National Economic University, «Ekonomichna dumka», Ternopil, Vol. 18, Issue 2, pp. 239-245.

8. Mokeev V.V., Bunova E.V. and Perevedentseva A.V. (2015), “Analysing the Economic Stability of an Enterprise with the Help of Eigenstate Method", Procedia Engineering, Vol. 129, pp. 681-689.

9. Malek J. and Desai Tushar N. (2019), "Interpretive structural modelling based analysis of sustainable manufacturing enablers”, Journal of Cleaner Production, Vol. 238, 20 November.

10.Vinichenko I. and Kriuchok S. (2016), "The economic stability of the enterprise and its components”, Ahrosvit, Vol.24, pp.15-20. 
УДК 336.64

JEL: M41, C13

Штепенко Катерина Павлівна, старший викладач. Свистун Людмила Анатоліївна, кандидат економічних наук, доцент. Крекотень Ірина Михайлівна, кандидат економічних наук, доцент. Національний університет «Полтавська політехніка імені Юрія Кондратюка». Планування ділової активності та оцінювання їі впливу на фінансову стабільність підприсмства. На сучасному етапі розвитку підприємства як відкритої соціально-економічної системи актуальним залишається питання, наскільки існуючі методики аналізу фінансового стану задовольняють потреби користувачів 3 огляду на динамічність і багатогранність господарських процесів. Метою статті $є$ обгрунтування релевантних залежностей між статичними та динамічними показниками фінансового стану, які відображають такі його характеристики, як ділова активність і фінансова стійкість. Виявлено функціональну залежність між динамічними показниками ділової активності та статичними показниками фінансової стійкості, обгрунтовано методику факторного аналізу фінансової стійкості. Визначено економічний зміст співвідношення показників оборотності активів та власного капіталу та встановлено характер його взаємозв'язку з динамікою активів. Теоретичним і практичним шляхом виявлено, що якщо співвідношення показників оборотності активів і власного капіталу більше за коефіцієнт фінансової незалежності на початок досліджуваного періоду, то позитивна динаміка вартості майна матиме негативний вплив на кінцеву фінансову стійкість підприємства, i навпаки, якщо це співвідношення буде меншим за коефіцієнт фінансової незалежності на початок досліджуваного періоду, вплив позитивної динаміки вартості майна на кінцеву фінансову стійкість буде позитивним. Запропоновано враховувати цю залежність як для ретроспективного факторного аналізу, так і для прогнозування фінансової стійкості.

Ключові слова: фінансовий стан, фінансова стійкість, ділова активність, фінансові коефіцієнти, оцінювання впливу, фінансове планування.

UDC 336.64

JEL: M41, C13

Shtepenko Kateryna Pavlivna, Senior Lecturer. Svystun Lyudmyla Anatoliivna, PhD (Economics), Associate Professor. Krekoten Iryna Mykhailivna, PhD (Economics), Associate Professor. National University "Yuri Kondratyuk Poltava Polytechnic". Business Planning and Assessment of Its Impact on the Enterprise Financial Stability. At the present stage of the company development as an open social and economic system the question of how existing methods of financial analysis meet the needs of users considering the dynamism and complexity of business processes remains relevant. The purpose of the article is study relationships between static and dynamic indicators of financial condition, to reflect its characteristics such as business activity and financial stability. The article defines the functional relationship between dynamic business activity indicators and static indicators of financial stability, grounds technique of factor analysis of financial stability. The economic content ratio of the assets turnover and equity is defined. The nature of its relationships with the dynamics of assets is considered. Both theoretically and practically it is determined that if the correlation of ratio of asset turnover and equity is bigger than the ratio of financial independence at the beginning of the period under study, the positive dynamics of the property will affect the company's final financial stability and vice versa, if the ratio is less than the rate of financial independence at the beginning of the period under study, the impact of positive dynamics of property on the final financial stability will be positive. It is proposed to consider this dependence both for factor retrospective analysis and for financial stability forecasting.

Keywords: financial condition; financial stability; business activity; financial ratios, impact assessment, financial planning. 